\title{
Nitrogen sufficiency index for estimating nitrogen fertilizer requirement of irrigated rice
}

\author{
Alberto Baêta dos Santos ${ }^{l}$, Mellissa Ananias Soler da Silval, Pedro Marques da Silveiral, \\ Glaucilene Duarte Carvalho ${ }^{2}$, Luís Fernando Stone ${ }^{1 *}$ (D)
}

$10.1590 / 0034-737 X 201966060003$

\begin{abstract}
The proper nitrogen management is required to achieve high irrigated rice yield. This study aimed to determine the rice response to nitrogen topdressing doses and calibrate the chlorophyll meter reading. Three experiments were conducted in a randomized block design. In the first experiment, five $\mathrm{N}$ rates $\left(0,30,60,90\right.$, and $\left.120 \mathrm{~kg} \mathrm{ha}^{-1}\right)$ were evaluated as the first, and $30 \mathrm{~kg} \mathrm{ha}^{-1} \mathrm{~N}$ as the second topdressing, which were combined with the application of $30 \mathrm{~kg} \mathrm{ha}^{-1} \mathrm{~N}$ as the first and five $\mathrm{N}$ rates, as the second topdressing. The other experiments assessed the application of $30 \mathrm{~kg} \mathrm{ha}^{-1} \mathrm{of} \mathrm{N}$, as the first, and four $\mathrm{N}$ rates $\left(0,40,80\right.$, and $\left.120 \mathrm{~kg} \mathrm{ha}^{-1}\right)$, as the second topdressing. There was a response to $\mathrm{N}$ application, with maximum technical efficiency reaching $33 \mathrm{~kg} \mathrm{ha}^{-1}$ in the first and between 40 and $50 \mathrm{~kg} \mathrm{ha}^{-1}$ in the second topdressing. The chlorophyll meter was sensitive to estimate the amount of $\mathrm{N}$ to be applied in topdressing, using the nitrogen sufficiency index (NSI). To each percent unit of NSI below 95\%, one should apply $10 \mathrm{~kg} \mathrm{ha}^{-1}$ of N as the first and 2-3 kg $\mathrm{ha}^{-1}$ of $\mathrm{N}$ as the second topdressing.
\end{abstract}

Keywords: Oryza sativa L.; N management; grain yield; nitrogen topdressing; chlorophyll meter.

\section{INTRODUCTION}

Conservation and sustainability of crop grain yield require good management practices of soil fertility. Nitrogen $(\mathrm{N})$ is the nutrient of greatest metabolic demand by plants, and its deficiency is usually a limiting factor for crop growth. The molecule chlorophyll contains nitrogen and has a significant participation in the increase of leaf area of the plant, which increases the interception of solar radiation and the photosynthetic rate, resulting in higher grain yield (Fageria \& Stone, 2003).

Rice cultivated in the flooded irrigation system is highly demanding for nutrients, and $\mathrm{N}$ is among those required in greatest amount, since it is an important factor to determine its productive potential (Fageria et al., 2008; Fageria, 2014). The lower grain yield of irrigated rice in the tropical region than in subtropical areas can be attributed to the reduction in the crop cycle and the lower response to fertilizers, especially N (Santos, 2004). N deficiency in irrigated rice occurs frequently in tropical floodplain soils. The main reasons for this occurrence are soil ammonia volatilization losses, gaseous losses of nitrogen oxides $\left(\mathrm{NO}_{2}, \mathrm{~N}_{2} \mathrm{O}, \mathrm{NO}\right)$ and elemental nitrogen $\left(\mathrm{N}_{2}\right)$, soil nitrate leaching out of the reach of roots, $\mathrm{NH}_{3}$ losses by the shoots (Fageria \& Baligar, 2005; Damin \& Soler-Silva, 2016), and decrease in the organic matter content from successive crops (Munda et al., 2018). In this context, a good $\mathrm{N}$ management is fundamental, both for reducing production costs and minimizing the effects of environmental pollution. $\mathrm{N}$ has an extremely complex dynamics in irrigated rice farming, with great variability in its chemical forms due to soil water content (aerobic or anaerobic conditions), which directly reflects the efficiency of nutrient utilization by the crop.

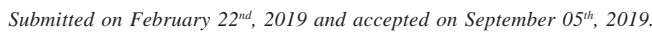

'Embrapa Arroz e Feijão, Santo Antônio de Goiás, Goiás, Brazil. alberto.baeta@embrapa.br; mellissa.soler@embrapa.br; pedro.silveira@embrapa.br; luis.stone@embrapa.br 2SECIMA - Secretaria de Estado de Meio Ambiente, Recursos Hídricos, Infraestrutura, Cidades e Assuntos Metropolitanos, Goiânia, Goiás, Brazil. glaucilene_agro@yahoo.com.br Corresponding author: alberto.baeta@embrapa.br
} 
Because most farmers have no access to plant analysis or other guidance method, mineral nitrogen fertilization is quantified by empirical visual analysis or based on traditional recommendations. Therefore, correct $\mathrm{N}$ diagnosis in the plant is essential for a proper management. Most of the methods available for this assessment are costly, destructive, and time consuming.

To date, no routine laboratory method has been developed that provides a satisfactory evaluation of the soil's ability to supply $\mathrm{N}$ to plants and recommendations, given the complexity and interactions between the transformation processes of this nutrient in the soil and climatic conditions (Fageria et al., 2019). Most of the $\mathrm{N}$ in the soil is in the organic form, which must be mineralized to be released and made available to plants. Thus, it is not possible to establish a calibration curve for this nutrient, and $\mathrm{N}$ recommendations are made based on the dose response curve.

The lack of synchronicity between the time of application and the time of the highest demand provides a low $\mathrm{N}$ recovery efficiency by the irrigated rice. These preestablished nitrogen doses may lead to underestimation or overestimation of fertilizer requirements. On the one hand, this can result in drop in grain yield and, on the other hand, in increased costs due to the unnecessary fertilizer amounts, leading to a decrease in the farmer's profit and a negative impact on the environment due to nitrate leaching and higher gas emissions by nitrification, i.e., the risk of environmental pollution. For a better synchronization of application and demand times, it has been suggested the monitoring of leaf $\mathrm{N}$ and chlorophyll levels as an alternative to conventional methods for the diagnosis. The handheld device chlorophyll meter (SPAD unit) provides readings corresponding to the content of the pigment in the leaf and has been used to estimate the $\mathrm{N}$ leaf content, since chlorophyll and $\mathrm{N}$ correlate positively in the same crop (Carvalho et al., 2012; Pocojeski et al., 2012) and with grain yield.

The chlorophyll meter monitors indirectly and nondestructively the nutritional status of $\mathrm{N}$ in the crop and can be used to estimate the need for nitrogen topdressing at different growth stages.

Several biotic and abiotic factors may affect the chlorophyll meter measurements of the intensity of green color in the leaf. In order to minimize this influence, a method has been recommended for normalizing the chlorophyll meter readings for each area, cultivar, growth stage, edaphoclimatic condition, and management practice (Hussain et al., 2000; Godoy et al., 2003; Rambo et al., 2007). One way to normalize the readings is to determine the $\mathrm{N}$ sufficiency index (NSI) by dividing the average of the readings done in the treatments to be fertilized by that done in a Reference Area. The Reference Area is a strip of the crop, with the same cultivar, fertilized with a much higher amount of $\mathrm{N}$ than the rest of the crop, so that in theory there is no $\mathrm{N}$ deficiency. The most frequently used NSI value is 0.95 . Therefore, when the value of NSI in the sample is below $95 \%$ of the reading in the Reference Area, nitrogen fertilization is necessary (Godoy et al., 2003; Rambo et al., 2007).

Santos et al. $(2011,2017)$ and Carvalho et al. (2018) conducted studies in the tropical region performing chlorophyll readings from the growth stages V3 - V4 to V11 - V12. The SPAD units or relative chlorophyll content of plants that received $\mathrm{N}$ increased to reach maximum values at the V7 - V8 stages and, afterwards, decreased and stabilized until the last reading. In these studies, the NSI values of the stages V3 - V4 and V7 - V8 indicated the need for $\mathrm{N}$ application.

The objective of this study was to determine the agronomic performance of irrigated rice as affected by $\mathrm{N}$ doses applied as the first (V3 - V4 stage) and as the second (V7 - V8 stage) topdressing and calibrate the chlorophyll meter reading with the crop response curve for the management of nitrogen fertilizer in tropical lowlands.

\section{MATERIAL AND METHODS}

The study was conducted in the experimental field of Palmital Farm, belonging to Embrapa Rice \& Beans, located in the municipality of Goianira, GO, between coordinates $16^{\circ} 26^{\prime} 45^{\prime \prime} \mathrm{S}$ and $49^{\circ} 23^{\prime} 31^{\prime \prime} \mathrm{W}, 729 \mathrm{~m}$ altitude, in the 2014-15 and 2016-17 harvest years. Three experiments were carried out in a Neofluvissolic Eutrophic Ta Haplic Gleysol, medium/medium-coarse texture, A moderate, phases flat relief, Stony III, hydrophilic floodplain (Oliveira \& Rodrigues, 2012). According to the Köppen-Geiger climatic classification (Kottek et al., 2006), the climate is "Aw", with annual average rainfall of $1,485 \mathrm{~mm}$ and annual average relative humidity of $71 \%$.

The first experiment tested the effects of five $\mathrm{N}$ doses applied as the first topdressing and a fixed dose of $30 \mathrm{~kg}$ $\mathrm{ha}^{-1} \mathrm{~N}$ applied as the second topdressing combined with the application of $30 \mathrm{~kg} \mathrm{ha}^{-1} \mathrm{~N}$ as the first topdressing and five $\mathrm{N}$ doses as the second topdressing, in the form of urea, on the performance of irrigated rice. The doses 0,30 , 60,90 , and $120 \mathrm{~kg} \mathrm{ha}^{-1}$ of $\mathrm{N}$ were applied at the vegetative growth stage V3 - V4 (pre or early tillering) and at the V7 V8 (effective tillering), according to the scale of Counce $e t$ al. (2000).

Prior to fertilizer applications, we used the SPAD502 (Minolta, 1989) (SPAD-Soil Plant Analysis Development) chlorophyll meter to monitor the $\mathrm{N}$ status in 25 plants. The readings were taken on the middle third of the last fully expanded leaf of the rice plants, from 9:00 to 10:00 a.m. 
In order to normalize the readings obtained by the chlorophyll meter, we established a Reference Area which received $180 \mathrm{~kg} \mathrm{ha}^{-1} \mathrm{~N}$ as three applications of $60 \mathrm{~kg} \mathrm{ha}^{-1} \mathrm{~N}$, corresponding to twice the recommended dose, which is $90 \mathrm{~kg} \mathrm{ha}^{-1} \mathrm{~N}$, to ensure no deficiency of nitrogen. Using these data, we determined NSI with the formula:

$$
\text { NSI }(\%)=\frac{\begin{array}{c}
\text { average values of readings in plants } \\
\text { of the area to be fertilized with } \mathrm{N}
\end{array}}{\begin{array}{c}
\text { average values of readings in plants } \\
\text { of the Reference Area }
\end{array}} \times 100
$$

The second and third experiments tested the effects of $30 \mathrm{~kg} \mathrm{ha}^{-1} \mathrm{~N}$ applied as the first $\mathrm{N}$ topdressing and four doses of $0,40,80$, and $120 \mathrm{~kg} \mathrm{ha}^{-1}$ of $\mathrm{N}$ as the second topdressing on the performance of irrigated rice.

The three experiments were carried out with cv. BRS Catiana for the irrigated condition, with long and thin grains, and average cycle of 121 to 135 days. It is recommended for the majority of states with significant irrigated rice production in the tropical region. The cultivar stands out for its translucent grains, low incidence of chalky grains, and good cooking quality with soft and loose grains. It has wide adaptation, high productive potential and tolerance to lodging, with the stay-green phenotype showing later senescence. In addition, it also stands out for the excellent grain quality and moderate resistance to the main diseases that attack irrigated rice crops (Morais et al., 2016)

The three experiments were arranged in a randomized block design, with four replications. Land was prepared by harrowing and leveling of the area. At sowing, $20 \mathrm{~kg} \mathrm{ha}^{-1}$ of $\mathrm{N}, 40 \mathrm{~kg} \mathrm{ha}^{-1}$ of $\mathrm{P}_{2} \mathrm{O}_{5}$, and $55 \mathrm{~kg} \mathrm{ha}^{-1}$ of $\mathrm{K}_{2} \mathrm{O}$ were applied according to the recommendation based on soil fertility analyses. The chemical analyses and grain size of soil samples collected at the beginning of the study in the 0$0.20 \mathrm{~m}$ layer showed the following characteristics: $\mathrm{pH}\left(\mathrm{H}_{2} \mathrm{O}\right)$ : 5.2 and 5.2; $\mathrm{Ca}^{2+}: 29.5$ and $22.7 \mathrm{mmol}_{\mathrm{c}} \mathrm{dm}^{-3} ; \mathrm{Mg}^{2+}: 14.6$ and $6.5 \mathrm{mmol}_{\mathrm{c}} \mathrm{dm}^{-3} ; \mathrm{Al}^{3++}: 2.8$ and $4.6 \mathrm{mmol}_{\mathrm{c}} \mathrm{dm}^{-3} ; \mathrm{P}: 37.6$ and $49.8 \mathrm{mg} \mathrm{dm}^{-3} ; \mathrm{K}^{+}: 79.8$ and $65.5 \mathrm{mg} \mathrm{dm}^{-3} ; \mathrm{Cu}: 1.7$ and $7.4 \mathrm{mg}$ $\mathrm{dm}^{-3} ; \mathrm{Zn}: 2.2$ and $5.9 \mathrm{mg} \mathrm{dm}^{-3}$; Fe: 268.3 and $364.2 \mathrm{mg} \mathrm{dm}^{-3}$; Mn: 19 and $24 \mathrm{mg} \mathrm{dm}^{-3}$; Clay: 414 and $238 \mathrm{~g} \mathrm{dm}^{-3}$, Silt: 254 and $242 \mathrm{~g} \mathrm{dm}^{-3}$, and Sand: 331 and $519 \mathrm{~g} \mathrm{dm}^{-3}$, in the experiments 1 and $2 / 3$, respectively.

Sowing was performed on dry soil, using rows spaced $0.17 \mathrm{~m}$ apart and 80 seeds per meter. Flooding started shortly after the first topdressing fertilization at the V3 - V4 stage. During irrigation, the water depth was uniformly maintained at about $0.12 \mathrm{~m}$. Interruption of irrigation occurred only at the R8 - R9 stage, at complete grain maturation.

Plant samples collected at harvest were separated into straw (leaves + sheaths + stems) and grain, and dried in an oven at $60{ }^{\circ} \mathrm{C}$ to determine the straw dry mass
(DMstraw) and total shoot dry mass (Biomass). Still, at harvest time, the following variables were recorded: number of tillers and panicles in $1 \mathrm{~m}^{2}$, grain number and empty spikelets per panicle, 100-grain weight, and plant height, determined in ten panicles, and grain yield, expressed as $\mathrm{kg} \mathrm{ha}^{-1}$ after moisture adjusted to $13 \%$. Spikelet fertility was determined by dividing the number of grains per panicle by the total number of spikelets and expressing the result as percentage. Grain harvest index (GHI) was obtained by the ratio between the grain yield and Biomass in $1 \mathrm{~m}^{2}$. N use efficiency was calculated by the formula: Agronomic Efficiency of $\mathrm{N}(\mathrm{AEN})=\left(\mathrm{PG}_{\mathrm{wf}}-\right.$ $\left.\mathrm{PG}_{\mathrm{wof}}\right) /\left(\mathrm{QN}_{\mathrm{a}}\right)$ expressed as $\mathrm{kg} \mathrm{kg}^{-1}$, where $\mathrm{PG}_{\mathrm{wf}}$ is production of grains with nitrogen fertilizer; $\mathrm{PG}_{\mathrm{wof}}$ is the production of grains without nitrogen fertilizer; $\mathrm{QN}_{\mathrm{a}}$ is the quantity of $\mathrm{N}$ applied in kilograms (Fageria \& Baligar, 2005; Fageria, 2014).

Data were analyzed by analysis of variance and the effects of $\mathrm{N}$ doses by regression analysis. After estimation of maximum grain yield (MEY) based on the $\mathrm{N}$ response curve, the maximum technical efficiency (MET) was determined. As an economic criterion for fertilizer recommendation, MET is normally considered to be $90 \%$ of MEY (Fageria et al., 2007; Fageria et al., 2008). However, due to the importance of $\mathrm{N}$ for irrigated rice, in this study MET was considered equal to $0.95 \mathrm{MEY}$.

\section{RESULTS AND DISCUSSION}

$\mathrm{N}$ rates influenced differently some agronomic traits of cv. BRS Catiana (Table 1). In the first experiment, the number of panicles per area increased linearly with the $\mathrm{N}$ doses applied at early tillering. This indicates that application of $\mathrm{N}$ at the pre- or early tillering stage results in a higher number of panicles per area, which is defined in the vegetative phase and contributes the most to grain yield (Fageria, 2007). This yield component had similar behavior with the second topdressing in the third experiment. Therefore, a larger number of panicles per area can also be obtained with nitrogen fertilizations carried out at the effective tillering stage. Camargo et al. (2008) reported that the formation of rice panicles increases with $\mathrm{N}$ addition prior to booting. Fageria (2007), Fageria et al. (2007), and Fageria \& Santos (2015) found that the number of panicles of irrigated rice increased with $\mathrm{N}$ fertilization.

The number of grains per panicle was not influenced by nitrogen fertilization, while the 100 -grain weight decreased in the first experiment and increased in the third experiment, with the $\mathrm{N}$ rates applied as the second topdressing. Fageria et al. (2007) and Santos et al. (2016) found no effect of $\mathrm{N}$ doses on grain weight of irrigated rice genotypes. However, Fageria et al. (2007) reported that 
grain weight and grain yield shown a positive, but not significant, correlation, which demonstrates its less importance for increasing yield in the rice crop.

The spikelet fertility decreased linearly with the increase in the $\mathrm{N}$ doses applied as first and second topdressing. Fageria et al. (2007) stated that in irrigated rice the spikelet sterility is a genotype characteristic and can be modified by using $\mathrm{N}$.

The $\mathrm{N}$ doses influenced DMstraw and rice biomass in the first experiment, showing quadratic effects in the first topdressing, with peaks at the doses 111 and $86 \mathrm{~kg} \mathrm{ha}^{-1}$ of $\mathrm{N}$, respectively, and increasing linearly in the second topdressing. In the second experiment, there was a linear response of DMstraw and quadratic of biomass, peaking at $87 \mathrm{~kg} \mathrm{ha}^{-1} \mathrm{~N}$. In the third experiment, these agronomic traits responded linearly to the $\mathrm{N}$ doses, increasing 4.3 and $6.6 \mathrm{~g} \mathrm{~m}^{-2}$ in dry matter per each $\mathrm{kg}$ of $\mathrm{N}$ applied, respectively. Fageria et al. (2008) evaluated the performance of irrigated rice genotypes to nitrogen fertilization and found a quadratic association between biomass and grain yield.
The dry matter yield responses to $\mathrm{N}$ doses were reflected in the height of the plants, which increased linearly. GHI showed linear negative response to the increasing doses of $\mathrm{N}$ applied as the first and second topdressing, indicating that the increase in straw dry matter was greater than the increase in grain yield.

In this study, we found $\mathrm{N}$ sufficiency indices (NSI) below $95 \%$, indicating, therefore, the time of greatest need for $\mathrm{N}$ application, which is similar to the results obtained by Santos et al. $(2011,2017)$ and Carvalho et al. (2018), who verified the need for $\mathrm{N}$ application at the V3 - V4 and V7 - V8 stages of rice growth.

Considering the crop response to the application of nitrogen in field conditions, in the first experiment, the maximum grain yields of 9,791 and $10,040 \mathrm{~kg} \mathrm{ha}^{-1}$ were estimated (MEY) at doses of 74 and $77 \mathrm{~kg} \mathrm{ha}^{-1}$ of $\mathrm{N}$ as first and second topdressing, respectively (Table 2).

Furthermore, studies on plant nutrition have been using the maximum technical efficiency (MTE) as an economic criterion for fertilizer recommendations. MTE corresponds to the same yield obtained by using a smaller

Table 1: Regression equations of agronomic traits of irrigated rice cultivar BRS Catiana as a function of $\mathrm{N}$ doses applied as topdressing and determination coefficients $\left(\mathrm{R}^{2}\right)$, in three experiments

\begin{tabular}{|c|c|c|}
\hline Trait & Regression equation & $\mathbf{R}^{2}$ \\
\hline \multicolumn{3}{|c|}{ First experiment } \\
\hline \multicolumn{3}{|c|}{ First topdressing } \\
\hline Panicle $\left(\mathrm{n}^{\mathrm{o}} \mathrm{m}^{-2}\right)$ & $y=567.69+1.5294 x$ & $0.621^{*}$ \\
\hline Spikelet fertility (\%) & $\mathrm{y}=86.30-0.0889 x$ & $0.838^{*}$ \\
\hline DMstraw $\left(\mathrm{g} \mathrm{m}^{-2}\right)$ & $y=626.88+11.5080 x-0.0518 x^{2}$ & $0.942^{* *}$ \\
\hline Biomass $\left(\mathrm{g} \mathrm{m}^{-2}\right)$ & $y=1450.45+22.3354 x-0.1293 x^{2}$ & $0.903^{* *}$ \\
\hline Plant height $(\mathrm{cm})$ & $y=85.63+0.1723 x$ & $0.993^{* *}$ \\
\hline GHI & $\mathrm{y}=0.57-0.0010 x$ & $0.990^{* *}$ \\
\hline \multicolumn{3}{|c|}{ Second topdressing } \\
\hline 100-grain weight (g) & $y=2.88-0.0022 x$ & $0.860^{* *}$ \\
\hline Spikelet fertility (\%) & $\mathrm{y}=81.74-0.0732 \mathrm{x}$ & $0.767^{* *}$ \\
\hline DMstraw $\left(\mathrm{g} \mathrm{m}^{-2}\right)$ & $y=721.43+3.7199 x$ & $0.720^{* *}$ \\
\hline Biomass $\left(\mathrm{g} \mathrm{m}^{-2}\right)$ & $y=1505.40+7.8992 x$ & $0.709^{* *}$ \\
\hline Plant height $(\mathrm{cm})$ & $\mathrm{y}=88.46+0.1252 \mathrm{x}$ & $0.886^{* *}$ \\
\hline \multicolumn{3}{|c|}{ Second experiment } \\
\hline DMstraw $\left(\mathrm{g} \mathrm{m}^{-2}\right)$ & $y=647.64+2.0868 x$ & $0.794^{* *}$ \\
\hline Biomass $\left(\mathrm{g} \mathrm{m}^{-2}\right)$ & $y=1313.56+12.1656 x-0.0699 x^{2}$ & $0.996^{* *}$ \\
\hline Plant height $(\mathrm{cm})$ & $\mathrm{y}=81.08+0.0831 \mathrm{x}$ & $0.934^{* *}$ \\
\hline \multicolumn{3}{|c|}{ Third experiment } \\
\hline Panicle $\left(\mathrm{n}^{\mathrm{o}} \mathrm{m}^{-2}\right)$ & $y=503.53+1.6508 x$ & $0.914^{* *}$ \\
\hline 100-grain weight (g) & $y=2.64+0.0019 x$ & $0.431^{* *}$ \\
\hline Spikelet fertility (\%) & $\mathrm{y}=78.48-0.0231 \mathrm{x}$ & $0.635^{* *}$ \\
\hline DMstraw $\left(\mathrm{g} \mathrm{m}^{-2}\right)$ & $\mathrm{y}=581.94+4.2851 \mathrm{x}$ & $0.931^{* *}$ \\
\hline Biomass $\left(\mathrm{g} \mathrm{m}^{-2}\right)$ & $y=1292.93+6.6201 x$ & $0.955^{* *}$ \\
\hline Plant height $(\mathrm{cm})$ & $\mathrm{y}=78.67+0.1330 \mathrm{x}$ & $0.979^{* *}$ \\
\hline GHI & $y=0.55-0.0007 x$ & $0.955^{* *}$ \\
\hline
\end{tabular}

$*$ and $* *$ Significant at $5 \%$ and $1 \%$ probability level. 
quantity of production factors or at least one of them, above which there is no response from the crop that justifies increasing the amount of the nutrient. Considering the MEY obtained by the response curve of the irrigated rice cv. BRS Catiana, MTE, that is, $95 \%$ of the MEY, was determined on the same curve, and the doses 33 and $42 \mathrm{~kg} \mathrm{ha}^{-1}$ of $\mathrm{N}$ were estimated to be applied as first and second topdressing, respectively.

Based on the chlorophyll meter readings, NSI were calculated for the first experiment:

First topdressing NSI $(\%)=(34.91 / 38.07) \times 100=91.69 \%$

Second topdressing NSI $(\%)=(26.78 / 38.00) \times 100=$ $70.47 \%$

In the normalization of the chlorophyll meter readings, $\mathrm{N}$ well-nourished plants are considered to have $95 \%$ NSI. With this, it is necessary to establish the factor to be used for determining the $\mathrm{N}$ dose to be applied as the first topdressing, based on the chlorophyll meter. This was done by dividing $33 \mathrm{~kg} \mathrm{ha}^{-1}$ of $\mathrm{N}$ that was estimated on the response curve by the difference between $95 \%$ and the calculated NSI, which was $91.69 \%$, that is:

Factor for determination of N dose = MTE / (95- NSI).
The result obtained is factor 10 , that is, $33 / 3.3=10$.

Similarly, the $\mathrm{N}$ dose to be applied in the second nitrogen topdressing, based on chlorophyll meter readings, was determined by dividing $42 \mathrm{~kg} \mathrm{ha}^{-1} \mathrm{~N}$ calculated on the response curve by the difference between $95 \%$ and the NSI, which was $70.47 \%$. Thus, factor 2 is obtained as a whole number, that is, $42 / 24.53=2$. With this methodology, the doses calculated to be applied to the irrigated rice crop are 33 and $49 \mathrm{~kg} \mathrm{ha}^{-1}$ of $\mathrm{N}$ as first and second topdressing, which corresponds to 10 and $2 \mathrm{~kg} \mathrm{ha}^{-1}$ of $\mathrm{N}$ per each percentage point below $95 \%$ of NSI. On the other hand, to calculate the maximum estimated yield (MEY) of 9,791 kg $\mathrm{ha}^{-1}$ grain, the factor used to determine the nitrogen fertilization should be changed from 2 to 3 , which would imply the application of $74 \mathrm{~kg} \mathrm{ha}^{-1}$ of $\mathrm{N}$ as the second topdressing.

In the second experiment, considering cv. BRS Catiana's response curve, the maximum yield of 8,040 $\mathrm{kg} \mathrm{ha}^{-1}$ grain was estimated (MEY) at the dose $81 \mathrm{~kg} \mathrm{ha}^{-}$ ${ }^{1} \mathrm{~N}$ and MTE of 7,638 $\mathrm{kg} \mathrm{ha}^{-1}$ grain was calculated at the dose of $47 \mathrm{~kg} \mathrm{ha}^{-1} \mathrm{~N}$ as the second topdressing (Table 3 ). Using the NSI obtained from $78.25 \%$ and, therefore,

Table 2: Maximum grain yield estimated (MEY) based on the response curve of the irrigated rice cultivar BRS Catiana, maximum technical efficiency (MTE) (95\% MEY) and calculation of N dose based on NSI, in the first experiment

\begin{tabular}{ccc}
\hline \multicolumn{3}{c}{ First topdressing } \\
\hline & Regression equation & $\mathrm{R}^{2}$ \\
\hline Grain yield & $\mathrm{y}=8154.51+44.2859 \mathrm{x}-0.2996 \mathrm{x}^{2}$ & $0.841^{* *}$ \\
\hline MEY $\left(\mathrm{kg} \mathrm{ha}^{-1}\right)$ & & $\mathrm{N}$ Dose $\left(\mathrm{kg} \mathrm{ha}^{-1}\right)$ \\
9791 & 74 \\
\hline MTE $\left(\mathrm{kg} \mathrm{ha}^{-1}\right)$ & $\mathrm{N}$ Dose $\left(\mathrm{kg} \mathrm{ha}^{-1}\right)$ \\
9302 & 33 \\
\hline
\end{tabular}

Calculation of $\mathbf{N}$ dose in the first topdressing based on NSI ${ }^{1}$

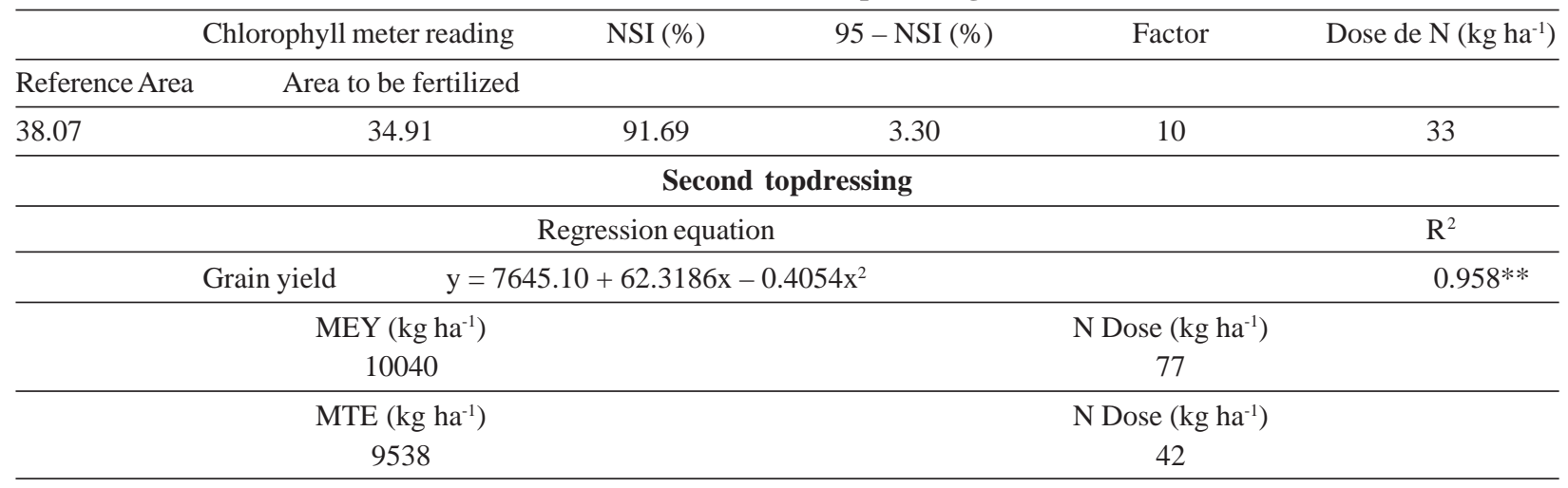

Calculation of $\mathbf{N}$ dose in the second topdressing based on NSI

\begin{tabular}{lccccc}
\hline & Chlorophyll meter reading & NSI $(\%)$ & 95 - NSI $(\%)$ & Factor & \\
\hline Reference Area & Area to be fertilized & & & \\
\hline 38.00 & 26.78 & 70.47 & 24.53 & 2 & 39 \\
& & & & 34 \\
\hline
\end{tabular}

\footnotetext{
${ }^{1} \mathrm{~N}$ sufficiency index

** Significant at $1 \%$ probability
}

Rev. Ceres, Viçosa, v. 66, n.6, p. 422-430, nov/dec, 2019 
a difference of $16.75 \%$ below $95 \%$ of the reading in the Reference Area, which is a value that takes into account $\mathrm{N}$ well-nourished plants, we obtained the factor 3 , as a whole number, that is, 47/16.75. With this methodology, the dose estimated to be applied to the irrigated rice crop as the second topdressing is $50 \mathrm{~kg} \mathrm{ha}^{-1} \mathrm{~N}$, which corresponds to $3 \mathrm{~kg} \mathrm{ha}^{-1} \mathrm{~N}$ per each percentage point below $95 \%$ of NSI.

In the third experiment, the maximum yield of $8,236 \mathrm{~kg}$ $\mathrm{ha}^{-1}$ grain was estimated (MEY) at the dose $97 \mathrm{~kg} \mathrm{ha}^{-1} \mathrm{~N}$ and MTE of 7,824 kg ha ${ }^{-1}$ grain was calculated at the dose $52 \mathrm{~kg} \mathrm{ha}^{-1} \mathrm{~N}$ as the second topdressing (Table 3). Using the NSI obtained from $78.83 \%$ and, therefore, a difference of $16.17 \%$ below $95 \%$ of the reading in the Reference Area, a value that takes into account $\mathrm{N}$ well-nourished plants, we obtained the factor 3, as a whole number, that is, 52/ 16.17. Therefore, the dose estimated to be applied as the second topdressing is $49 \mathrm{~kg} \mathrm{ha}^{-1} \mathrm{~N}$, which corresponds to $3 \mathrm{~kg} \mathrm{ha}^{-1} \mathrm{~N}$ per each percentage point below $95 \%$ of NSI. This dose allows the production of grain yields very close to those estimated by MTE.
Grain yield increased with increasing N, but the agronomic efficiency of $\mathrm{N}$ (AEN) decreased because of the plant's lower capacity for nutrient uptake and utilization (Table 4).

This decrease is also related to relatively smaller increases with the successive increments of $\mathrm{N}$ doses, as well as the possibility of higher $\mathrm{N}$ losses through different processes (Fageria, 2014). AEN declined linearly with $\mathrm{N}$ doses increasing in the range from 50 to $180 \mathrm{~kg} \mathrm{ha}^{-1}$. There was a negative linear relationship between $\mathrm{N}$ dose and AEN in the first and second topdressing, as well as in the total $\mathrm{N}$ application. On average, AEN varied from 29 to 41 $\mathrm{kg}$ grain produced per $\mathrm{kg}$ of total $\mathrm{N}$ applied, which corroborates the findings of Fageria et al. (2013), who reported an average of $40 \mathrm{~kg}$ grain per $\mathrm{kg}$ of $\mathrm{N}$ applied. Maximum $\mathrm{N}$ agronomic efficiencies were 56 and $65 \mathrm{~kg}$ of grain produced per $\mathrm{kg}$ of $\mathrm{N}$ applied, which was obtained with $30 \mathrm{~kg} \mathrm{ha}^{-1}$ of $\mathrm{N}$ as first and second topdressing, and $55 \mathrm{~kg}$ grain obtained with up to $90 \mathrm{~kg}$ of total $\mathrm{N}$ applied. Santos et al. (2017) and Carvalho et al. (2018) obtained higher $\mathrm{N}$ use efficiencies in irrigated rice with nitrogen

Table 3: Maximum grain yield estimated (MEY) based on the response curve of the irrigated rice cultivar BRS Catiana, maximum technical efficiency (MTE) (95\% MEY) and calculation of N dose based on NSI, in the in the second and third experiments

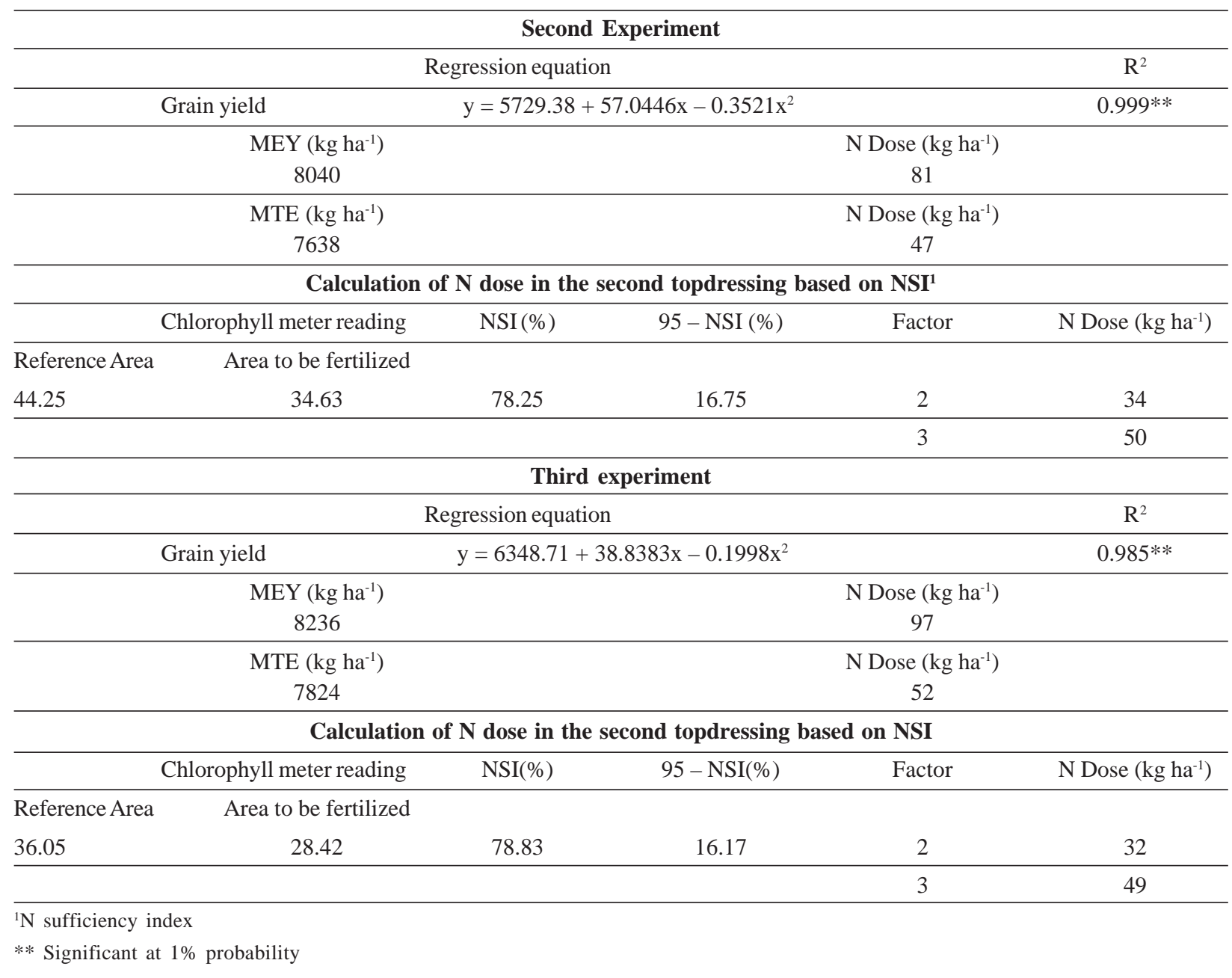


fertilizer applied according to chlorophyll meter readings than with $\mathrm{N}$ applied according to the local recommendation, which is based on pre-fixed times. Higher $\mathrm{N}$ use efficiency may contribute to increase grain yield (Fageria et al., 2007).

The chlorophyll meter readings were sensitive to estimate $\mathrm{N}$ content in the irrigated rice, allowing a response adjusted to the maximum technical efficiency (MTE) determined by the crop response curve to the application of $\mathrm{N}$ in field conditions.
The factors estimated to reach the appropriate level (95\%) were 10 and 2 to $3 \mathrm{~kg} \mathrm{ha}^{-1}$ of $\mathrm{N}$ in the first and second topdressing applications, respectively, per each percentage unit of increase in NSI.

Several studies to monitor $\mathrm{N}$ status in the rice crop have been carried out successfully different of countries (Balasubramanian et al., 2000; Hussain et al., 2000; Santos et al., 2011; Pocojeski et al., 2012) as an alternative to conventional methods of topdressing fertilization.

Table 4: Grain yield of the irrigated rice cultivar BRS Catiana and agronomic efficiency of N (AEN) as a function of N dose in both topdressing applications and total $\mathrm{N}$

\begin{tabular}{|c|c|c|c|c|}
\hline \multicolumn{2}{|c|}{ N Dose (kg ha-1) } & $\frac{\text { Grain yield }\left(\mathrm{kg} \mathrm{ha}^{-1}\right)}{\text { First experiment }}$ & \multicolumn{2}{|c|}{$\operatorname{AEN}\left(\mathrm{kg} \mathrm{kg}^{-1}\right)$} \\
\hline First topdressing & $\mathbf{N}$ total & & First topdressing & $\mathbf{N}$ total \\
\hline 0 & 60 & 7969 & - & 54 \\
\hline 30 & 90 & 9652 & 56 & 55 \\
\hline 60 & 120 & 9530 & 26 & 40 \\
\hline 90 & 150 & 9546 & 18 & 32 \\
\hline 120 & 180 & 9273 & 11 & 25 \\
\hline Mean & & & 28 & 41 \\
\hline
\end{tabular}

N Dose in the first topdressing $x$ AE N=63.68-0.4807x. $R^{2}=0.869^{* *}$

Total N x AEN $=72.79-0.2650 x . \mathrm{R}^{2}=0.936^{* *}$

\begin{tabular}{lcccc}
\hline Second topdressing & N total & & Second topdressing & N total \\
\hline 0 & 60 & 7514 & - & 46 \\
30 & 90 & 9457 & 65 & 52 \\
60 & 120 & 9791 & 38 & 42 \\
90 & 150 & 9841 & 26 & 34 \\
120 & 180 & 9373 & 16 & 26 \\
\hline Mean & & 36 & 40 \\
\hline
\end{tabular}

N Dose in the second topdressing x AE N=76.03-0.5334x. $\mathrm{R}^{2}=0.944^{* *}$

\begin{tabular}{lcccc}
\hline \multicolumn{5}{c}{ Second experiment } \\
\hline Second topdressing & N total & & Second topdressing & N total \\
\hline 0 & 36 & 5734 & - & 30 \\
40 & 76 & 7434 & 43 & 37 \\
80 & 116 & 8053 & 30 & 29 \\
120 & 156 & 7495 & 15 & 18 \\
\hline Mean & & & 29 & 29 \\
\hline & & Shird experiment & total \\
\hline Second topdressing & N total & & 23 & 55 \\
0 & 50 & 6468 & 30 & 41 \\
40 & 90 & 7401 & 14 & 26 \\
80 & 130 & 8884 & 22 & 41 \\
120 & 170 & 8144 & & \\
\hline Mean & & & & \\
\hline
\end{tabular}

\section{Regression}

Total N x AE N=64.65-0.2202x. $\mathrm{R}^{2}=0.923^{*}$

$*$ and $* *$ Significant at $5 \%$ and $1 \%$ probability level.

Rev. Ceres, Viçosa, v. 66, n.6, p. 422-430, nov/dec, 2019 


\section{CONCLUSIONS}

This study has shown that cultivar BRS Catiana responds in a quadratic manner to $\mathrm{N}$ fertilization, with maximum technical efficiency (MTE) achieved with $33 \mathrm{~kg}$ $\mathrm{ha}^{-1}$ applied as first topdressing and between 40 and $50 \mathrm{~kg}$ $\mathrm{ha}^{-1}$ as second topdressing.

The nitrogen sufficiency index (NSI) obtained with the chlorophyll meter readings allows the efficient estimation of the $\mathrm{N}$ amount to be topdressed to the irrigated rice.

The amount of $10 \mathrm{~kg} \mathrm{ha}^{-1}$ of $\mathrm{N}$ should be applied as the first topdressing and 2 to $3 \mathrm{~kg} \mathrm{ha}^{-1}$ of $\mathrm{N}$ as the second topdressing per each percentage unit of increase in NSI in order to reach the appropriate level (95\%).

The chlorophyll meter has proved to be a practical alternative to conventional methods for the determination of the $\mathrm{N}$ requirement of irrigated rice in tropical lowlands.

\section{ACKNOWLEDGMENTS}

The authors thank the National Council for Scientific and Technological Development (CNPq) for the financial support and the Scientific Initiation and Research Productivity grants.

\section{REFERÊNCIAS}

Balasubramanian V, Morales AC, Cruz R, Thiyagarajan TM, Nagarajan R, Babu M, Abdulrachman S \& Hai LH (2000) Adaptation of the chlorophyll meter (SPAD) technology for real-time $\mathrm{N}$ management in rice: a review. International Rice Research Institute, 05:25-26.

Camargo ER, Marchesan E, Rossato TL, Teló GM \& Arosemena DR (2008) Influência da aplicação de nitrogênio e fungicida no estádio de emborrachamento sobre o desempenho agronômico do arroz irrigado. Bragantia, 67:153-159.

Carvalho GD, Madari BE, Carvalho MT de M, Soler-Silva MA da; Santos AB dos; Costa AR da, Corrêa RS, Oliveira J de M, Leal WG de O, Souza DM de, Matsushige I \& Santos RCG dos (2018) Impacto do manejo da adubação nitrogenada sobre a emissão de gás de efeito estufa óxido nitroso e a produtividade de arroz (Oryza sativa L.) irrigado no cerrado. Santo Antônio de Goiás, Embrapa Arroz e Feijão. 23p. (Boletim de pesquisa e desenvolvimento, 52).

Carvalho MA de F, Silveira PM da \& Santos AB dos (2012) Utilização do clorofilômetro para racionalização da adubação nitrogenada nas culturas do arroz e do feijoeiro. Santo Antônio de Goiás, Embrapa Arroz e Feijão. 14p. (Comunicado técnico, 205).

Counce PA, Keisling TC \& Mitchell AJA (2000) Uniform, objective, and adaptive system for expressing rice development. Crop Science, 40:436-443.

Damin V, Soler-Silva MA. Manejo do nitrogênio na região de Cerrado (2016) In: Flores RA \& Cunha PP (Ed.) Práticas de manejo do solo para adequada nutrição de plantas no Cerrado. Goiânia, UFG. p.225-251.

Fageria NK (2014) Nitrogen management in crop production. New York, CRC Press. 408p.
Fageria NK (2007) Yield physiology of rice. Journal of Plant Nutrition, 30:843-879.

Fageria NK \& Baligar VC (2005) Enhancing nitrogen use efficiency in crop plants. Advances in Agronomy, 88:97-185.

Fageria NK, Barbosa Filho MP \& Alcântara FA de (2019) Fertilização do solo. In: Santos AB dos (Ed.) Árvore do conhecimento: arroz. Brasília, Embrapa. p. 125-135.

Fageria NK \& Santos AB dos (2015) Yield and yield components of lowland rice genotypes as influenced by nitrogen fertilization. Communications in Soil Science and Plant Analysis, 46:17231735.

Fageria NK, Santos AB dos \& Cutrim, V dos A (2008) Dry matter and yield of lowland rice genotypes as influence by nitrogen fertilization. Journal of Plant Nutrition, 31:788-795.

Fageria NK, Santos AB dos \& Cutrim V dos A (2007) Produtividade de arroz irrigado e eficiência de uso do nitrogênio influenciadas pela fertilização nitrogenada. Pesquisa Agropecuária Brasileira, 42:1029-1034.

Fageria NK, Santos AB dos \& Oliveira JP de (2013) Nitrogen-use efficiency in lowland rice genotypes under field conditions. Communications in Soil Science and Plant Analysis, 44:24972506.

Fageria NK \& Stone LF (2003) Manejo do nitrogênio. In: Fageria NK, Stone, LF Santos AB dos (Eds.) Manejo da fertilidade do solo para o arroz irrigado. Santo Antônio de Goiás, Embrapa Arroz e Feijão. p.51-94.

Godoy LJG de, Bôas RLV \& Grassi Filho H (2003) Adubação nitrogenada na cultura do milho baseada na medida do clorofilômetro e no índice de suficiência em nitrogênio (ISN). Agronomy, 25:373-380.

Hussain F, Bronson KF, Singh B \& Peng S (2000) Use of chlorophyll meter sufficiency indices for nitrogen management of irrigated rice in Asia. Agronomy Journal, 92:875-879.

Kottek M, Grieser J, Beck C, Rudolf B \& Rubel F (2006) World map of the Köppen-Geiger climate classification updated. Meteorologische Zeitschrift, 15:259-263.

Minolta câmera (1989) Manual for chlorophyll meter SPAD 502. Osaka, Radiometric Instruments divisions. 22p.

Morais OP de, Torga PP, Cordeiro ACC, Pereira JA, Magalhaes Júnior AM de \& Colombari Filho JM (2016) BRS Catiana: cultivar de arroz irrigado de elevada produtividade e ampla adaptação. Santo Antônio de Goiás, Embrapa Arroz e Feijão. 6 p. (Comunicado Técnico, 233).

Munda S, Bhaduri D, Mohanty S, Chatterjee D, Tripathi R, Shahid M, Kumar U, Bhattacharyya P, Kumar A, Adak T, Jangde HK \& Nayak AK (2018) Dynamics of soil organic carbon mineralization and $\mathrm{C}$ fractions in paddy soil on application of rice husk biochar. Biomass and Bioenergy, 115:01-09.

Oliveira VA \& Rodrigues C (2012) Levantamento detalhado dos solos da fazenda Palmital, município de Goianira - GO. Goiânia, Viasat. p.81.

Pocojeski E, Silva LS da, Bundt A da C, Marchesan E, Camargo E R \& Scivittaro WB (2012) Estimativa do teor de nitrogênio em arroz irrigado com o clorofilômetro e a cartela de cores. Ciência Rural, 42:1982-1988.

Rambo L, Silva PRF da, Strieder ML, Sangoi L, Bayer C \& Argenta G (2007) Monitoramento do nitrogênio na planta e no solo para predição da adubação nitrogenada em milho. Pesquisa Agropecuária Brasileira, 42:407-417.

Santos AB dos (2004) Importância e características. In: Santos $\mathrm{AB}$ dos (Ed.) Cultivo da soca de arroz irrigado. Santo Antônio de Goiás, Embrapa Arroz e Feijão. p.15-36. 
Santos AB dos, Fageria NK, Caldas PP de C \& Botelho TH (2011) Uso do clorofilômetro como indicador da necessidade de adubação nitrogenada em cobertura em arroz irrigado. In: $7^{\circ}$ Congresso Brasileiro de Arroz Irrigado, Balneário Camboriú. Anais, Epagri. p.493-496.

Santos AB dos, Fageria NK, Stone LF \& Santos TPB (2016) Effect of irrigation and nitrogen fertilization on the agronomic traits and yield of irrigated rice. Revista Ceres, 63:724-731.
Santos AB dos, Santos TPB, Filippi MCC de, Alves KD, Botelho THA \& Caldas PP de C (2017) Utilização de sensor portátil para recomendação de adubação nitrogenada associada ao uso de fungicidas em arroz irrigado. Revista Brasileira de Agropecuária Sustentável, 07:86-95. 